\title{
The Influence of Co-creation on Creative Industry Performance in Indonesia
}

\author{
AMIR MACHMUD \\ Faculty of Business and Economic Education \\ Universitas Pendidikan Indonesia, \\ INDONESIA
}

\author{
RIYANDI NUR SUMAWIDJAJA \\ Management Study Program, STIE Indonesia Membangun, INDONESIA
}

\begin{abstract}
This study aims to analyze and test the hypothesis of the effect of co-creation on the performance of the creative industries in Indonesia. Co-creation measurements with Across Interaction, Product Options, Access and Price Experience, while Firm Performance (Financial, Customer, Internal Business Process, Learning and Growth Perspective). The study method uses explanatory survey with data collection techniques using a questionnaire. The population in this study, SMEs engaged in the creative industries in West Java, Indonesia with a total of 1,571. With slovin sampling technique obtained 252 respondents. The collected data is then analyzed using the Structural Equation Model (SEM). The results of the study show that co-creation has a significant effect on the performance of creative industry SMEs in Indonesia, and the proposed hypothesis is accepted. This finding implies that to win the competition, SMEs must be able to improve their performance through the ability to innovate. Besides that This study implies to improve the performance of creative industry, it is necessary to improve the co-creation process such as increasing across-interactions, increasing the diversity of product options, and facilitating access to information on products.
\end{abstract}

Keywords: Co-creation, Firm Performance, Creative Industry, Indonesia

Received: July 25, 2019. Revised: May 12, 2020. Accepted: May 15, 2020. Published: May 18, 2020.

\section{Introduction}

The growth of creative industries in Indonesia experienced a varied and encouraged increase from various creative industry sub-sectors. The creative industry has contributed to the national economy, where the creative industry contributed $7.38 \%$ to the national economy by absorbing a workforce of 15.9 million people [1]. The Ministry of Industry has noted that the contribution of creative industries has continued to increase on gross domestic product (GDP) in the last three years. In 2015 this sector contributed IDR 852 trillion, while in 2016 it reached IDR 923 trillion and increased to IDR 990 trillion in 2017, 2018 is projected to be more than IDR 1,000 trillion [2] [3]. The role of the creative industry is very important to economic growth, both on a large business scale or the scale of micro small and medium enterprises (SMEs). In Indonesia, the development of the creative economy in the economy is still dominated, especially in the micro, small and medium scale industries (SMEs) which empower many laborers, the utilization of local natural resources and national cultural wealth, so that they deserve attention in their development.

In general, the performance of creative industry companies in Indonesia has not shown a good enough position. This is evident from the results of the 2016 \& 2017 Global Competitiveness Index measurements, showing Indonesia's position at 41 and 36 of 137 members [1],[2],[3]. In the ASEAN member region, Indonesia's 2017 competitiveness index ranks 4th after Singapore (3), Malaysia (23), Thailand (34). One of the weaknesses that occurs is the weak ability of Indonesian entrepreneurs in terms of the ability to innovate which results in less than optimal business performance [3]

Company performance has become a relevant concept in management science research and is often used as a dependent variable. Although this is a very 
general idea in academic literature, there is almost no consensus on its definition and measurement. Performance as a result of work that can be achieved by a person or group of people in a company in accordance with their respective authorities and responsibilities in an effort to achieve corporate goals legally, does not violate the law and does not conflict with morals or ethics [4], [5]. Performance is defined as the record of outcomes produced on a specified job function or activity during a specified time period. "[6]. Organizational performance as the extent to which an organization as a social system can consider the means and objectives [7], [8]. Organizational performance as a concept of success or effectiveness of an organization and indicates the effectiveness of the organization to achieve its goals successfully [9].[10], [11].

The most concise performance indicator is growth itself, which is often considered more accessible than accounting indicators and superior to corporate financial performance indicators [12], [13], [14], [15] Other researchers also consider performance from a multidimensional perspective [16], [17], [18]. which shows that in empirical studies, it is good to cover various dimensions of performance. One concept of performance measurement that takes into account various dimensions is the Balance Scorecard. This concept was popularized by [19], until now this concept is still used, so that company performance is measured internally / externally and financially and non-financially.

The Balance Scorecard indicators are: 1) Financial Perspective, related to profitability through measurement of operating profit, Return On Capital Employed (ROCE) or Economic Value Added, sales growth and cash flow; 2) Customer Perspective, the main measures are customer satisfaction, customer retention, acquisition of new customers, customer profitability, and market share in the target segment; 3) Internal Business Process Perspective, in this perspective executives identify various important internal processes that must be well controlled by the company; 4) Learning and Growth Perspective, identifying infrastructure that companies must build in creating growth and improving long-term performance. The main sources of company learning and growth are human, company systems and procedures [19], [20], [21], [22].
Organizations work to analyze, think, and design various ways to meet the needs and demands of consumers [23], [24] have observed the role of organizations in the process of value creation, according to them the organization acts as a catalyst to activate, shape, and accelerate value creation. Cocreation is a medium to improvise innovation and the ability to create value in a company together with fostering customer relationships [24], [25], [26]. The advantages of value creation are better product quality [27], greater customer satisfaction [28], and reducing risk for the company [29], [30]. Cocreation is a concept that illustrates a new approach to innovation consisting of the creation of products and experiences through collaboration with consumers, suppliers, other companies, and channel partners connected in a network that is profitable for innovation [31]. As one of one manifestation of customer involvement [32], the value of co-creation with customers in product development has become a strategic necessity for the company [33]. In the context of product development, joint creation can be defined as a 'product development activity' new collaborative approach in which consumers actively contribute and choose various elements of new products' offerings [34].

There are five types of co-creation [35] implemented by several companies to support their success in gaining market attention, namely 1) Co-creation Workshops, in this type of consumers who are involved in a workshops session to produce an idea; 2) Crowd Sourcing, by asking questions in the form of a problem and then giving gifts to people who give prizes for the "best idea" of the interaction is good because getting ideas from direct consumers automatically we will get solution ideas developed by consumers themselves; 3) Open Source, there are active volunteers with a large number involved in product development and maintenance. Open source is often implemented by developing software, it is suitable for you if you want to apply a new standard technique. Companies that successfully run with open source types include Linux, Firefox, and nonprofit organizations such as Creative Commons, 4) Mass Customization, where consumers can design their own products according to the desires of consumers, in other words consumers can choose the form of product, material, and product color. However, consumers also have to pay a small amount of money because it is considered a premium 
product. Examples of successful companies using mass customization types are Nike ID, and Lego Factory and 5) User Generated Content, consumers can make their own products by sharing systems, this usually applies to digital products and services. Companies that use this type are YouTube, Flickr, and Slideshare.

Future competition depends on a new approach to value creation that is based on the creation of shared value that adheres to individuals among customers and companies [36] . Dialogue, access, risk assessment and transparency are basic principles that companies must have in order can successfully implement shared value creation [36]. Companies also need to focus on the dimensions of choice of their interactions with customers that must condition their co-creation experience well [36]. Co-creation is defined as an active collaboration process, creative, and social relationships between producers and consumers, assisted by organizations [37]. All cocreation approaches have two general qualities, namely: (1) widening organizational boundaries, (2) involvement of co-creators [30]. Company performance usually uses a collection of ideas, strategies $i$ and has its own unique approach to cocreation that is specific in its aim to increase the productivity of a company's performance.

Co-creation dimensions consist of 1) Across Interaction Although many assumptions of technological advancements can revolutionize channels in the industry, they are unaware that channel choices, whether made by companies or customers, can form a co-creation experience of fundamental shared creation experiences, 2) Product Options. Consumers want to make choices that reflect their view of value. Companies must be able to provide experience centric options that reflect the wants and needs of consumers, 3) Access. Access between companies and consumers is the traditional basis of the value extraction process. Access includes logistics, information, channels and costs, as well as business between the two parties, and 4) Price Experience The business world often views product performance and prices using a company perspective. Businesspeople usually negotiate prices with costs, creating prices based on the company's financing structure.
Studies on performance and Co-creation are still few, especially in the case of creative industries in developing countries, but studies of the two variables have been conducted in Iran [38], Hairdressing and Aesthetics sector companies in Spain [39], financial performance in companies listed on the S \& P500 [40], and other companies both financial and nonfinancial performance have a relationship with cocreation [41], [42], [43], [44], [45]. This research shows there are direct impacts and positive between co-creation on company performance.

This study aims to analyze and re-examine hypotheses about the effect of co-creation on the performance of creative industry companies in Indonesia. The findings are expected to be used as input for policy makers related to industry performance by taking into account aspects of the ability to innovate.

\section{Problem Formulation}

The method used is Quantitative with the explanatory survey to test the conceptual model that describes the relationship between constructs of Co-Creation and business performance. Business performance is measured by 4 indicators, namely: Financial Perspective (Y1), Customer Perspective (Y2), Internal Business Process Perspective (Y3) and Learning \& Growth Perspective (Y4) [19], [20], [21], [22]. The dimensions of co-creation Across Interaction, Product options, Acess dan Price experience [36]

The research framework was built to determine the effect of co-creation on firm performance in reference to previous relevant research. The model proposed in this study is shown in Figure 1.

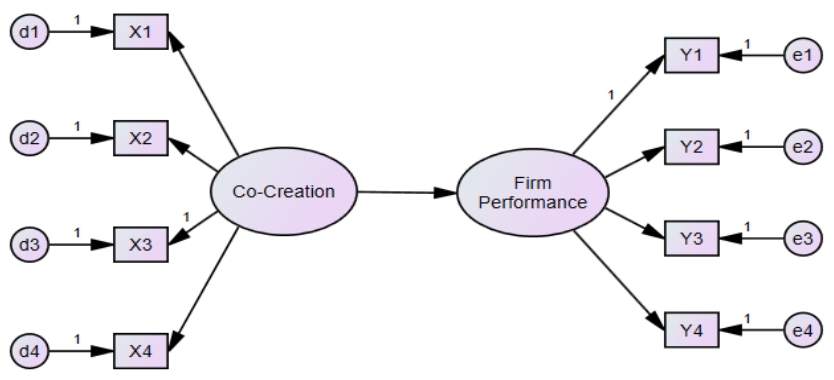

Fig.1. Proposed Research Framework 
To determine the effect of co-creation on firm performance, the hypothesis developed is as follows:

H1: Co-creation influences business performance

Data collection uses a Likert scale questionnaire 1-5. The population in this study were SMEs the manufacturing sector in West Java, Indonesia measuring 1.571, with proportional random sampling techniques, obtained sample size 252 . To test the effect of co-creation on firm performance, Structural Equation Modeling (SEM) AMOS is used.

\section{Problem Solution}

The results of the measurement model test for cocreation and firm performance are shown in Figure 2.

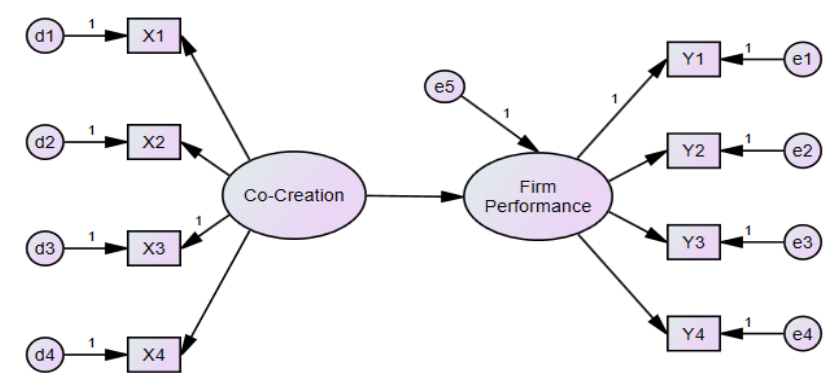

Fig.2. SEM Measurement Results

The test results of the measurement model of cocreation and firm performance in Table 1 show the value of loading factor $(\lambda)>0.5$, the value of $C R$ above 0.7 and VE above 0.5 so it can be concluded that co-creation and firm performance have validity and construct reliability the good one.

Table 1. Model of Measurement

\begin{tabular}{|c|c|c|c|c|c|c|}
\hline Variable & Indicator & $\lambda$ & $\lambda^{2}$ & $\mathrm{e}$ & CR & $\mathrm{VE}$ \\
\hline \multirow[t]{4}{*}{ Co-Creation } & $\mathrm{X} 1$ & 0,865 & 0,748 & 0,252 & \multirow[t]{4}{*}{0,913} & \multirow[t]{4}{*}{0,725} \\
\hline & $\mathrm{X} 2$ & 0,822 & 0,676 & 0,324 & & \\
\hline & $\mathrm{X} 3$ & 0,846 & 0,716 & 0,284 & & \\
\hline & $\mathrm{X} 4$ & 0,872 & 0,760 & 0,240 & & \\
\hline \multirow[t]{4}{*}{ Firm Performance } & Y1 & 0,952 & 0,906 & 0,094 & \multirow[t]{4}{*}{0,936} & \multirow[t]{4}{*}{0,787} \\
\hline & Y2 & 0,852 & 0,726 & 0,274 & & \\
\hline & Y3 & 0,814 & 0,663 & 0,337 & & \\
\hline & Y4 & 0,923 & 0,852 & 0,148 & & \\
\hline
\end{tabular}

$\lambda=$ Loading Factor, e=error, $\mathrm{CR}=$ composite reliability,

$\mathrm{VE}=$ variance extracted

Source: SEM AMOS Output
The normality test results in Table 2 note that not all indicators have a critical ratio of skewness values below 2.58, meaning that not all variables observed are normally distributed. Similarly, the multivariate normality test gives the value c.r. $(8.950)>2.58$ which shows that multivariate data is not normally distributed.

Table 2. Assesment of Normality

\begin{tabular}{lrrrrrr}
\hline Variable & min & max & skew & c.r. & kurtosis & c.r. \\
\hline Y4 & 2,000 & 10,000 & 1,166 & 7,557 &, 298 &, 967 \\
\hline Y3 & 2,000 & 9,000 &, 365 & 2,365 &,- 984 & $-3,188$ \\
\hline Y2 & 2,000 & 10,000 &, 148 &, 960 &, 339 & 1,099 \\
\hline Y1 & 2,000 & 10,000 & 1,419 & 9,197 & 1,852 & 6,001 \\
\hline $\mathbf{X 1}$ & 2,000 & 10,000 &,- 877 & $-5,683$ &, 908 & 2,944 \\
\hline $\mathbf{X 2}$ & 2,000 & 9,000 &,- 223 & $-1,444$ &,- 593 & $-1,921$ \\
\hline $\mathbf{X 3}$ & 2,000 & 9,000 & $-1,106$ & $-7,171$ & 2,403 & 7,786 \\
\hline $\mathbf{X 4}$ & 4,000 & 10,000 &, 071 &, 457 &,- 456 & $-1,479$ \\
\hline Multivariate & & & & & 14,263 & 8,950 \\
\hline
\end{tabular}

Testing of multivariate outliers is done by taking into account the value of Mahalanobis distance $\left(\mathrm{d}^{2}\right)$. Referring to Table 3, the maximum Mahalanobis distance $\left(\mathrm{d}^{2}\right)$ value $(31,248)<\mathrm{X}^{2}(71,234)$ is known. Thus multivariate there are no cases of outliers in the data.

Table 3. Outliers Data Mahalanobis d-squared

\begin{tabular}{ccc}
\hline Max & Min & $X^{2}$ \\
\hline $\mathbf{3 1 , 2 4 8}$ & 7,602 & 71,234 \\
\hline
\end{tabular}

Multicollinearity evaluation can be seen through the Determinant of sample covariance matrix and Condition number. The determinant value is very small and the Condition number is greater than 1000 , indicating an indication of multicollinearity or singularity problems so that the data cannot be used for research [46]. Referring to Table 4, it can be seen that the value of the Determinant of sample covariance matrix $(2,055)>0$ and Condition number $(45,883)<1000$, so it can be concluded there are no multicollinearity and singularity problems in the analyzed data.

Table 4. Multikolinieritas

\begin{tabular}{cc}
\hline $\begin{array}{c}\text { Determinant of sample } \\
\text { covariance matrix }\end{array}$ & $\begin{array}{c}\text { Condition } \\
\text { number }\end{array}$ \\
\hline 2,055 & 45,883 \\
\hline
\end{tabular}

Based on the assumption evaluation test results, it can be seen that the data distribution is not normal but multivariate there are no outliers in the data and 
the sample data sets empirically still meet the main statistical assumptions, namely there is no multicollinearity problem [47].

The test of the Goodness of Fit model in Table 5 shows that not all measures of the research model fit the data, but overall the research model is Fit, because GFI and AGFI $\geq 0.90$, RMSEA $\leq 0.08$, and NFI, CFI and TLI $\geq 0.90[30]$.

Table 5. Goodness of Fit

\begin{tabular}{ccc}
\hline GoF Index & Cut-off Value & Result \\
\hline RMSEA & $\leq 0,08$ & 0,079 \\
\hline GFI & $\geq 0,90$ & 0,934 \\
\hline AGFI & $\geq 0,90$ & 0,875 \\
\hline RFI & $\geq 0,90$ & 0,940 \\
\hline IFI & $\geq 0,90$ & 0,970 \\
\hline TLI & $\geq 0,90$ & 0.955 \\
\hline CFI & $\geq 0,90$ & 0,970 \\
\hline NFI & $\geq 0,90$ & 0,959 \\
\hline
\end{tabular}

Table 6, shows that the high and low firm performance is positively influenced by co-creation, this can be seen from the value of the path coefficient $(\mathrm{SRW})>0$. SRW value of 0.596 shows that cocreation has an influence $\left(0.596^{2}=0.3552\right)$ on firm performance which means $35.52 \%$ of the variation that occurs in firm performance can be explained by co-creation. The remaining $64.48 \%$ is the influence of other variables not explained in the model. The test results show that co-creation has a positive and significant effect on firm performance.

Table 6. Regression Weights and Standardized Regression Weight

\begin{tabular}{|c|c|c|c|c|c|c|c|}
\hline & & & RW & SRW & S.E. & C.R. & $\mathbf{P}$ \\
\hline $\begin{array}{l}\text { Firm_- } \\
\text { Performance }\end{array}$ & $<$ & Co-Creation & 988 &, 596 &, 103 & 9,577 & $* * *$ \\
\hline $\mathrm{X} 4$ & $<$ & Co-Creation & 1,034 & 881 & 060 & 17,232 & $* * *$ \\
\hline $\mathrm{X} 3$ & $<$ & Co-Creation & 1,000 & 840 & & & \\
\hline $\mathrm{X} 2$ & $<$ & Co-Creation & 1,163 & 828 &, 075 & 15,490 & $* * *$ \\
\hline $\mathrm{XI}$ & $<$ & Co-Creation & 1,228 & 856 &, 073 & 16,850 & $* * *$ \\
\hline Y2 & $<$ & $\begin{array}{l}\text { Firm_- } \\
\text { Performance }\end{array}$ &, 790 &, 853 &, 037 & 21,555 & $* * *$ \\
\hline Y3 & $<$ & $\begin{array}{l}\text { Firm_- } \\
\text { Performance }\end{array}$ & 891 & 819 & .046 & 19,282 & $* * *$ \\
\hline Y1 & $<$ & $\begin{array}{l}\text { Firm } \\
\text { Performance }\end{array}$ & 1,000 & 952 & & & \\
\hline Y4 & $<$ & $\begin{array}{l}\text { Firm_- } \\
\text { Performance }\end{array}$ & 1,089 & 920 & 039 & 27,973 & $* * *$ \\
\hline
\end{tabular}

The research findings show that the low application of co-creation has a positive effect on the low capacity for innovation. Positive coefficient means the lower the application of co-creation the lower the capacity to innovate. This finding is consistent with the results of research by [38] showing the relationship that co-creation influences the capacity / ability to innovate in a company or proven that cocreation has a positive and direct impact on the ability / capacity to innovate. The same thing also happened to the results of research conducted by [40] with the development of innovation models obtained by the relationship that co-creation affects the ability / capacity to innovate. While research conducted by [48], [49] shows that co-creation influences innovation (product innovation).

This finding reinforces the research conducted by [39] where the results of the study show the relationship that co-creation influences the ability / capacity to innovate. This is evidenced by the low implementation of co-creation causing low capacity to innovate.

\section{Conclusion}

Co-creation tends to be low, so does company performance tends to be low. Thus there is a positive influence of co-creation on company performance, which shows co-creation can explain variations that occur in company performance in accordance with the research model.

The tendency of low co-creation capability and company performance if continued and allowed to have an impact will be the lower involvement of the community in producing products, the diversity of product choices produced and the lack of product information, so that the creative industry SMEs will find it difficult to retain customers and reach new customers, which will affect on the company's financial and non-financial performance.

This research is limited to the variables of entrepreneurial competence, co-creation, capacity to innovate as exogenous variables that affect company performance as endogenous variables, and do not examine other variables that may have a greater influence on improving company performance. therefore the researcher recommends further research that uses other variables

\section{References}


[1] Sumawidjaja, R.N., Suryana, Ahman, E., Machmud, A. (2019). The impact of entrepreneurial competencies on creative industry performance in Indonesia. Journal of Entrepreneurship Education

[2] Eeng Ahman, Amir Machmud, Riayandi Nur Sumawidjadja, Erna Herlinawati (2020). Model of The Competitive Advantage of Creative Industries in Indonesia based on Helix Quadruple, Creativity and Innovation Capability. International Journal of Innovation, Creativity and Change. www.ijicc.net Volume 11 , Issue 8.

[3] Herlinawati, E., Ahman, E., \& Machmud, A. (2019). The Effect of Entrepreneurial Orientation on SMEs Business Performance in Indonesia. Journal of Entrepreneurship Education

[4] Rivai, V., \& Basri, A. F. M. (2005). Performance Appraisal: Sistem yang tepat untuk menilai kinerja karyawan dan meningkatkan daya saing perusahaan. PT RajaGrafindo Persada.

[5] Herlinawati, E., Ahman, E., \& Machmud, A. (2019). The Effect of Entrepreneurial Orientation on SMEs Business Performance in Indonesia. Journal of Entrepreneurship Education.

[6] Bernardin, J. H. \& Russel, J. A. (1998). Human resource management: An experiental approach. Mc Graw-Hill

[7] Georgopoulos, B. S., \& Tannenbaum, A. S. (1957). A study of organizational effectiveness. American sociological review, 22(5), 534-540.

[8] Machmud, A., \& Ahman, E, Effect Of Entrepreneur Psychological Capital And Human Resources On The Performance Of The Catering Industry In Indonesia. Journal of Entrepreneurship Education, 22(1), 2019, 1-7

[9] Cameron, K. S. (1994). Strategies for successful organizational downsizing. Human Resource Management, 33(2), 189-211.

[10] Herlinawat, E., Machmud, A,. (2020). The effect of innovation on increasing business performance of SMEs in Indonesia WSEAS TRANSACTIONS on BUSINESS and ECONOMICS, Volume 17, 2020

[11] Machmud, A., \& Hidayat, Y. M. (2020). Characteristics Of Islamic Entrepreneurship And The Business Success Of Smes In
Indonesia. Journal of Entrepreneurship Education, 23(2).

[12] Fombrun, C., \& Shanley, M. (1990). What's in a name? Reputation building and corporate strategy. Academy of management Journal, 33(2), 233-258.

[13] Tsai, W. MacMillan, I., \& Low, M. (199)1. Effects of strategy and environment on corporate venture success in industrial markets. Journal of Business Venturing, 6(1) pp. $9-28$

[14] Brush. \& Vander, W. (1992). A comparison of methods and sources for obtaining estimates of new venture performance. Journal of Business Venturing, 7 (2) pp. 157-170.

[15] Chandler, G.N. \& Steven H. H. (1994). Founder competence, the environment, and venture performance. SAGE Journal .

[16] Lumpkin, G. T. \& Dess G. G. (1996). Clarifying the entrepreneurial orientation construct and linking it to performance. The Academy of Management Review, 21 (1) pp. 135-172

[17] Lumpkin, G. T., \& Dess, G. G. (2015). Entrepreneurial orientation. Wiley Encyclopedia of Management, 1-4.

[18] Wiklund, J. (1998). Entrepreneurial orientation as predictor of performance and entrepreneurial beh aviour in small firms: Longitudinal evidence. Frontiers of entrepreneurship research, 18.

[19] Kaplan, R.S. \& Norton, D.P. (1992). The Balanced scorecard-Measures That Drive Performance, Harvard Business Review, 1992, 71-79.

[20] Kaplan, R.S. \& Norton, D.P, Balanced scorecard. Jakarta: Erlangga, 1996

[21] Kaplan, R.S. \& Norton, D.P, Alignment: Using the balanced scorecard to create corporate synergies. Boston: Harvard Business School Press, 2006.

[22] Neely, A, Business performance measurement: theory \& practice. Cambridge University Press, 2004.

[23] Sheth, J. N., Sisodia, R. S., \& Sharma, A. (2000). The antecedents and consequences of customer-centric marketing. Journal of the Academy of marketing Science, 28(1), 55-66.

[24] Sawhney, R., \& Chason, S. (2005). Human behavior based exploratory model for successful implementation of lean enterprise in 
industry. Performance

Improvement

Quarterly, 18(2), 76-96.

[25] Vivek, S. D., Beatty, S. E., \& Morgan, R. M. (2012). Customer engagement: Exploring customer relationships beyond purchase. Journal of marketing theory and practice, 20(2), 122146.

[26] Stamm, U. (2004). Extreme ultraviolet light sources for use in semiconductor lithographystate of the art and future development. Journal of Physics D: Applied Physics, 37(23), 3244.

[27] Füller, J., \& Matzler, K. (2007). Virtual product experience and customer participation-A chance for customer-centred, really new products. Technovation, 27(6-7), 378-387.

[28] Nambisan, S., \& Baron, R. A. (2010). Different roles, different strokes: Organizing virtual customer environments to promote two types of customer contributions. Organization Science, 21(2), 554-572.

[29] Hoyer, W. D., Chandy, R., Dorotic, M., Krafft, M., \& Singh, S. S. (2010). Consumer cocreation in new product development. Journal of service research, 13(3), 283-296.

[30] Roser, T., DeFillippi, R. \& Samson, A. (2013) Managing Your Co-Creation Mix, Co-Creation Ventures in Distinctive Contents. European Business Review, 25 (1).

[31] Prahalad, C. K., \& Ramaswamy, V. (2004). The future of competition: Co-creating unique value with customers. Harvard Business Press.

[32] Dorotic, M., Bijmolt, T. H., \& Verhoef, P. C. (2012). Loyalty programmes: Current knowledge and research directions. International Journal of Management Reviews, 14(3), 217237.

[33] Jaakkola, E., Helkkula, A., Aarikka-Stenroos, L., \& Verleye, K. (2015). The co-creation experience from the customer perspective: its measurement and determinants. Journal of Service Management.

[34] Hoyer, W. D., Chandy, R., Dorotic, M., Krafft, M., \& Singh, S. S. (2010). Consumer cocreation in new product development. Journal of service research, 13(3), 283-296..

[35] Indika, D. R., \& Soleh, C. M. P. (2017). Implementasi Co Creation dalam Pengembangan Produk pada Ritel Butik. ISEI Business and Management Review, 1(2), 96101.
[36] Prahalad, C.K. \& Ramaswamy, V. (2004). Cocreating unique value with customers. Strategy \& Leadership, 32(3) pp. 4-9

[37] Piller, F., Ihl, C., \& Vossen, A. (2011). Customer co-creation: Open innovation with customers. V. Wittke \& H. Hanekop, New forms of collaboration and Innovation in Internet, 3163.

[38] Fatemeh, H. \& Naser, G. (2017). Impact of Cocreation on innovation capability and firm performance: A Structural Equation Modeling. AD-minister no. 30 Januari-Juni, pp. 73-90.

[39] Silva, F.J., Camacho, M.A., \& Vázquez, M. (2013). Heterogeneity of customers of personal image services: a segmentation based on value co-creation. International Entrepreneurship Management Journal. 9, pp. 619-630.

[40] Payne, A.F.; Storbacka, K. \& Frow, P. (2008) Managing the co-creation of value. Journal of the Academy of Marketing Science, 36(1), pp. 83-96.

[41] Khramova, M. (2014). Co-creating value with customers as a new approach of entering new market.

[42] Tijmes, A. H. (2010). Co-creation and firm performance: innovation success enhancing effects of and motives for customer involvement (Master's thesis, University of Twente).

[43] Perks, H., Gruber, T., \& Edvardsson, B. (2012). Co-creation in radical service innovation: a systematic analysis of microlevel processes. Journal of Product Innovation Management, 29(6), 935-951.

[44] Zhang, J., Jiang, Y., Shabbir, R., \& Du, M. (2015). Building industrial brand equity by leveraging firm capabilities and co-creating value with customers. Industrial Marketing Management, 51, 47-58.

[45] Babyak, A., \& Bell, L. (2018). Customer Satisfaction as an Antecedent to Engagement in Co-Creation of Value in the Hotel Industry.

[46] Tabachnick, B. G., \& Dan Fidel, L. S. (2007). Using Multivariate Statistics. USA: Person Education Inc.

[47] Maholtra, N. K. (2010). Marketing Research an Applied Orientation. 6th edition. New Jersey: Pearson education Inc, Prentice Hall.

[48] Verma, R., Gustafsson, A., Kristensson, P., \& Witell, L. (2012). Customer co-creation in service innovation: a matter of 
communication?. Journal of service management.

[49] Pee, L. G. (2016). Customer co-creation in B2C e-commerce: does it lead to better new products?. Electronic Research, 16(2), 217-243.

Commerce 